\title{
Commodification of Science and Paradoxes in Universities
}

\author{
Luísa Oliveira
}

There is emerging a new development model based on a competitive "innovation pattern" which has spurred a debate on the relationship between universities and industry. Even though science and its applications have always fed economic growth, this question takes on a completely new form today. Universities are given direct responsibility for national competitiveness, which implies assuming new functions and changing those which it has traditionally been attributed with (Etzkowitz \& Peters, 1991). Europe is trying to follow this model, which originated in the United States. Its virtues lie in the economic success provided by the quantity of technological innovations and new markets. Technological innovation is understood as a new product which can be commercialised. It is not enough to be a "novelty" if it cannot be turned into a product (Oliveira 2000). European universities are confronted with a set of challenges, which question their models and try to adapt to new contexts according to societal specificities (Maurice et al., 1982). The results of this process are still unclear.

This paper starts by discussing the origin of the "modern university", also known as the Humboldt model. This discussion brings the role of science in economic development to light and the way in which universities have integrated the function of research while trying to retain their independence from the state. Brief reference is made to the historic development of science in the USA, together with some illustrative notes on the transformation of science and universities. The following section discusses the possibility of importing the American model to Europe and argues that the importance of philosophy in the development of the Humboldt model is giving way to economic theory, in a framework of technocratisation of politics (Habermas, 1973). The reference to the Portuguese case attempts to show the "sociological density" which marks the difference between countries and which 
resists the importation of economic models.

\section{The Invention of the "Modern" University: Academic Functions and Knowledge}

The challenges to universities today are essentially the same as those, which marked the emergence of the "modern" university about 200 years ago. The Humboldt model of the university is the classical reference to the idea of the “modern” university (Renaut, 1995), consolidated in the formation of Berlin University in 1810. This occurred following the first great academic crisis marked by the secularisation process of the university in the Middle Ages. This change was marked by the transfer from a dependence on the Church to a dependence on the state and by the emergence of a new type of knowledge - science as opposed to religious knowledge. This process was also marked by a change in the university's functions, which became not only a place for teaching, but also a place for the production of scientific knowledge, a process some authors call the first academic revolution (Etzkowitz \& Leydesdorff, 1997). Strong debate broke out in Germany at that time over the conception of universities and science in which German philosophy played a fundamental role (Renaut, 1995). One of the great themes of this debate was the relationship between the university and the state. It was feared that the state, in pursuit of its own interests, would reduce the university's mission to the training of civil servants needed by the state itself. The question of "disinterested knowledge" as opposed to professional training was raised for the first time.

At the time, the question of autonomy ran along two main themes: internal autonomy and external autonomy. The problems raised by the former referred to the relationship between education and research. The production of knowledge and its transmission were distinct tasks and not subject to the same demands. The extent to which teaching must subordinate research, why and in what circumstances was discussed. Each country gave a different answer to this question and developed its own trajectories. These trajectories mark the main differences between universities and, generally speaking, the organisation of the so-called national innovation systems (Lundvall, 1992; Nelson, 1993).

Today this question is as pressing as ever, as can be seen by the importance given to international comparisons in an attempt to reach conclusions on the advantages and disadvantages of each model. The problem with these comparisons would seem to be the criteria on which to decide what is "advantageous," given the prevailing idea that the system should obey a principle of economic rationality. (Ferné, 1993) A second important question was the kind of knowledge the university was to transmit. Even if research was considered on an equal footing with teaching - understood at the time as "pure and disinterested research" - the transmitted knowledge corresponded to a "specialised high culture." On giving priority to teaching, knowledge would be "less refined" and more professionalising. Another theme raised in the discussion of internal autonomy referred to the relationship between the disciplines within the university and to the internal organisation 
brought about by the relationship between faculties, the university as well as within the faculties themselves. External autonomy, on the other hand, referred to the relationship between the university and the state. This question has been present throughout the history of the modern university, although the suppositions on which this discussion has been based have not always been the same. Autonomy has been defended in the name of academic freedom based on "disinterested knowledge," as well as from a liberal stance, which argues that it is just one of society's institutions, like any other, with its own interests.

The history of the modern university, however, cannot be separated from the history of science (Caraça, 1999). The relation between the conciliation of "pure science" and the economic needs during the first industrial revolution, which, in broad terms, corresponded to the opening of the university as a place to produce science. Science academies had appeared to some extent all over Europe much earlier - during the 17th and 18th centuries - in the philosophical context, which considered that the progress of science depended on its use.

Leibnitz, the first president of the Berlin Science Academy in 1700, made his name by identifying the purely theoretical sciences and their practical applications. Using this framework, he made a considerable effort to found academies - outside universities - based on the idea of the "productive sciences" (see Bowker, 1996). Today questions can be raised concerning the factors, which explain the expansion of the universities up till the present day when they could be expected to have a role in training the elite. The answer seems to lie in the univer- sity model which Humboldt developed in response to this controversy when he founded the Berlin University - and it is not by chance that the Humboldtian model has influenced universities almost all over the world, including the USA. The Berlin University simultaneously came out against the utilitarian idea of science - of which the academies and the higher and special schools were an example - and against the medieval ecclesiastic university model. It is essential to understand that for Humboldt, it would be an enormous threat, both for the university and for science, to treat universities as specialised schools and divide research into pure and applied research. Humboldt owed his success to the compromise he was able to make between the two: universities would be responsible for pure research (in the sense of searching for the truth) that should also include a practical component. In teaching, this option would be translated into the famous formula of "training through research."

Three important aspects essential to the current debate on universities are considered:

1. There is an essential difference between "science as a search for truth" and "science as a search for a response to economic and political interests". This is a fundamental question and should not be confused with basic research versus applied research.

2. The Humboldt model permits a conception of the university, which is relatively independent of the state, the economy and society, though through a kind of mythical representation of science that thrived at the time. 
3. The implications of each of these options in the nature of academic knowledge. It was implicit that this "knowledge" was not pledged as "ready-to-use skills," in accordance with the specific interests of the market. ${ }^{1}$ The prevailing idea of the Berlin University project was that professional skills did not come directly from the sphere of scientific knowledge, but were acquired by imitating the traditional "knowing-doing" models.

On the other hand, the "search for the truth" and "training through research," provided an overall vision of the world and an integral training for Man and not just a profession. For Humboldt the mission of universities was also the " moral education of the nation."

\section{Science in Economic Development}

The role of science in development is not a new question, irrespective of how each country organised its research activities. The French Napoleonic model is an extreme case of this in the European context. For the analysis the American model was chosen, however, as it is the current reference model for Europe, both as a developmental model and as the inspiration of economic theory.

\section{The US Example}

As Caraça (1999) has argued, the 19th century was the century of mechanics, steel and railways. Its symbol was the engine; its concept mechanics and the Europeans seemed to be the masters of the world. As an analogy, we could say that the 21st century appears to be shaping as the century of information sci- ences, telecommunications and biotechnology. Its symbol is the computer, its concept information - "the information society." How was this point reached in terms of the university model and the development of science?

Historically, the American model was greatly influenced by the German model of Humboldt. Before this, the church's influence is not comparable with Europe (Peyrefitte, 1995). The United States had colleges like the English model of Oxford and Cambridge and, under Benjamin Franklin's influence, the prevailing idea was of a "useful culture" (Kerr, 1994). The opposition between fundamental research and research applied to economic interests re-emerged in the USA at the start of the 20th century primarily because of the appearance of the first industrial laboratories in large chemical and electrical enterprises. The First World War was another decisive step in this matter when private industry started financing university research activities with some regularity. According to Robert Millikan, this was the first time in history that the world was "...woken up by the war to an appreciation of what science could do..." (Geiger, 1988). Chemical weapons, the first air bombardments, submarines and later the Hiroshima disaster, however, ended and de-sanctified the neutrality of science.

After the Second World War, the Vannevar Bush report (1945) tried to clear the image of science. This proved a decisive step, not only in how science would develop, but also for the shaping of American universities. The financing of fundamental research was defended with the argument that the great technological developments during the war were only possible thanks to previous 
investment in fundamental research. It was also recognised that only the government was able to finance fundamental research given the large sums of financing required. This was Bush's objective when he proposed the setting up of the National Science Foundation. The government assumed the role of financing research considered relevant to national needs. This institutionalised a tripartite responsibility between political, military and economic power, as its roots had already been established by the experiences of collaboration with the industrial sector. As Geiger (1988) has argued, what is now currently called "technology transfer," was already the mission of the National Research Council (NRC) in America during the 1920's. The NRC co-ordinated the mobilisation of science during the First World War and continued in peace time as an intermediate institution with the aim of developing close cooperation between industry and academic science.

During the 1980's, the focus of industry changed to long term financing, even with examples of large European enterprises financing research activities in the USA. This change did not exclude the previous kind of collaboration, based more on cooperation on a limited time scale, consortiums and exchange of researchers between university and industry, for example. In more general terms, this new attitude from industry included a business strategy for reducing costs in reaction to the crisis of the 1970's (Boyer, 1981); this is expressed in the exteriorisation of the activities developed within the enterprises until that time, as well as the economic virtues of downsizing and entrepreneurship as important components of the new spirit of capitalism. To cut costs enterprises reduced employment both by firing and by slowing down recruitment. The unemployment generated in this way, would be resolved by the transformation of the unemployed and young into entrepreneurs. This is the entrepreneurial universities and the teacher entrepreneur philosophy. (Boltanski \& Chiapello, 1999)

At the same time, the emergence of new high-tech industries, such as telecommunications, computers and biotechnology as pillars of economic development of the 21st century, changed the traditional conception of science (Gibbons et al., 1994). Universities were a necessary condition to the new development model. Etzkowitz and Leydesdorff (1997) argue that the transition universities are going through is not a crisis, but a "second academic revolution." The first took place when universities assumed the role of research in addition to teaching and became research universities. The second, has been characterised by the institutionalisation of the economic function of the university - economic development becoming part of its mission -in which the actors involved have adapted and adjusted their positions to new institutional opportunities and constraints. "Channelling knowledge flows into new sources of technological innovation has become an academic task, changing the structure and function of university"(Etzkowitz \& Leydesdorff, 1997:1). This revolution has also had a number of consequences in the internal structure and organisation of the university, the change in science as such, the means of financing, the conception of scientific knowledge and in the researcher's profile. Here, I wish to retain the idea in the transformation of 
science, with regard to the effects on "knowledge." Scientific knowledge according to the traditional conception of science becomes another kind of scientific knowledge inherent to the new science.

\section{Reformulating Academic Functions and Knowledge}

According to Gibbons et al. (1994), there is a new way of producing science. Universities no longer hold a privileged place in this process of producing scientific knowledge. At the same time, this change means that knowledge is produced with other actors and institutions using new configurations. The process unleashes a set of challenges for universities requiring a structural change (Sousa Santos, 1994) and a profound reformulation of academic knowledge. The historical reasons explaining this situation originate from the actual model of traditional science, as distinguished from "new science," which was constructed by the scientist. "...[s]cientists long ago discovered that the most effective way to achieve this was through a process of specialisation in the cognitive realm, of professionalisation in the social realm and institutionalisation of the political realm" (Gibbons et al., 1994: 10). A standard was therefore defined over time for institutional science, which excluded everything that threatened it in some way. The main results of this process were the structuring of scientific knowledge into disciplines, a certain conception of science and scientists, a set of social norms for regulating the system and the identification of places/institutions, which participated in the construction and functioning of the scien- tific fabric.

The basis of this model has been eroded over time, essentially due to the massification of teaching and the appropriation of the research function by universities. With the growing number of people involved, it became possible to disseminate academic knowledge to society, forming a new means of producing knowledge no longer confined to the academic world: it is in public laboratories, industry, enterprises, research centres and consulting offices, that these activities are carried out.

Another equally important reason is the emergence of new technologies telecommunications and computer sciences - that permit the link between these (new) places where knowledge is produced. What is in question is a transformation of science as an institution and a professional reconversion of the teachers/scientists - also implicit in this process - as its main protagonists. This new knowledge exists and is economically useful, but not yet fully socially recognised. To distinguish these two knowledge production models Gibbons et al. (1994) use the term Mode 1 and Mode 2 of knowledge production to refer, respectively, to the conventional model of the functioning of science and the emerging one. The former refers to what is generally termed scientific knowledge and can be briefly defined as “... the cognitive and social norms which must be followed in the production, legitimisation and diffusion of knowledge" (Gibbons et al., 1994). Its protagonists are called scientists, a term which is no longer applicable in Mode 2, though the authors stress that this does not mean that they do not comply with the rules of scientific method. Accepting this 
model, which some authors have also called post-academic science (Ziman, 1999), means recognising not only the need for the reformulation of traditional academic knowledge, but also for a change in the professional identity (see Oliveira, 1998) of university teachers.

\section{Economic Theory and the Commercialisation of Science}

If we reduce the American experience to the societal specificity of which it is part and accept Etzkowitz's liberal optimism, which Europe is now trying to follow in the name of "globalisation" and "competition," it seems to be more realistic to consider that the 21st century brings about an academic crisis. In this crisis, the university tries to construct a new identity in a world where the decisive importance of philosophy gives way to economic theory and the technocratisation of policy (Habermas, 1973). This seems to be a clear case in which "economics, in the broad sense of the term, performs, shapes and formats the economy, rather than observing how it functions" (Callon, 1994: 51).

The first industrial revolution made it clear that "technical progress" was decisively important in the creation of wealth through its direct impact on the productivity of labour, employment, the creation of new products and markets. Marx had already called attention to the importance of science and technique in the development of capitalism. But Kuznets, in 1930, was the first economist to consider that "the distinctive feature of modern industrial societies is their success in applying systematised knowledge to the economic sphere, knowledge derived from scientific research" (Rosenberg,
1985: 32). Schumpeter (1935) goes furthest in this field when he considers "innovation" as the key to the explanation on how the capitalist system endlessly generates the energy, which transforms it. However, the crisis at the start of the 1930's, symbolically marked by the crash of the New York Stock Exchange in 1929, made economists acutely aware of the unemployment problem and the macroeconomic models of balance, making Schumpeter a marginal author in economics for a long time. Rosenberg has also called attention to the fact that "to exclude product innovation from technical progress...is to play Hamlet without the Prince." (Rosenberg, 1985: 32) In the aftermath of the economic crisis of the 1970 's, there was, in fact a partial re-examination of Schumpeter. The neoschumpeterians dedicated themselves to an analysis of the impact of innovation on economic growth. In this framework, innovation acquires a central position, like all the other factors that can influence its production. Science and the university enter into this debate as factors of decisive importance. The so-called theory of national innovation systems (Nelson, 1993; Lundvall, 1992) is a decisive step in this matter. The Triple-Helix (Etzkowitz \& Leydesdorf, 1997) goes even further.

It is enough to examine the official documents on the subject, including those of the OECD, $(1993 ; 1995)$ to understand how far the role of economic theory goes in defining science and technology, as well as industrial policies (see Lundval \& Borras, 1997). The "power of science", the " power in science" and the "power with science" which Caraça (1999) distinguishes to simplify the analysis, does not exist separately in re- 
ality. In fact, the scientific advisors closest to political and economic power and the importance given to science and technology, as the author says, are characteristic marks of our age.

A preliminary analysis of European policies in this field shows us that these same policies try to shape universities, which should not only assume the function of teaching and research but also one of economic growth. They try to go much further than the model of professional training on which the idea of the modern university had been founded. Humboldt leaves us with the idea of the university as a place for the production of research; what changes is the kind of research and the principle of academic freedom.

\section{The Need for a Historical and Sociological Understanding}

Attention should be drawn to the fact that economic reality is embedded, according to Granovetter (1973), with a sociological and historically constructed component. This sociological density, as I call it, is invisible to economic theory and resists the importation of economic and other models, which are foreign to it. This resistance, which is more or less in accordance with how foreign it is, may reject, assimilate or adapt them to the models. ${ }^{2}$ It is not unusual that the negative results of the evaluation of policies, for example, are due to a kind of blindness to the sociological reality, in its conception.

\section{The Changing Fortunes of History and the Portuguese University Model}

In Portugal, discussions concerning the modernisation of the Humboldt university is placed in different terms. If there was modernisation, it was in the secularisation of the system with the expulsion of the Jesuits and the "Pombal Reform" at the end of the 18th century. The Portuguese model followed the Napoleonic idea of universities more closely in that it was a strongly centralised institution, directly dependent on the Constitutional Monarchy and its vocation was more to provide professional training (Cruzeiro, 1990). The First Republic did not last long enough to implement structural reforms. Salazar's dictatorship led to the atrophy of the education system and the university was kept closed within itself and training reserved for the elite.

Without going into detail, it is worth underlining that during the 1960's Portugal was principally a rural country. The class structure was linked to the country, which was not concerned with social mobility based on investment in education (Vieira, 1995). Furthermore, the average standard of living of most families could not support the costs inherent in such a project. At the start of the 1970's the discussion focussed on the lack of economic resources, which resulted in a large majority of young people having to enter the labour market early. There were no universities destined to train people, such as France's Grands Écoles, because access to university was limited by the socioeconomic conditions of the family

The massification of higher education began in 1974 with the change of the political regime. In 1986 the Statutory Law of the Education System was ratified, which gave the universities an economic role. This was also the year Por- 
tugal entered the EU - a step, which would also lead to the introduction of profound structural reforms throughout the whole system. At the same time, the EU defined new legal grounds for the role of active communities in science and technology, which would have strong repercussions not only in Portugal, but in all EU countries. In short, for specific historical reasons higher education was democratised much later than in any other European country or the United States.

In the same way the relationship between teaching and research is very specific. At the end of the 1960's, it was estimated that there were about a hundred "teams" doing research (Dias Agudo, 1969) in which more than half had only one or two full time researchers. A number of other factors contributed to the almost complete absence of research in higher education, notably the lack of laboratories, equipment and libraries. A divorce between teaching and research in universities was therefore nourished and the idea of the Napoleonic model was accentuated with the difference that in 1920 France founded the Centre Nationale de Recherche Scientifique (CNRS), which it entrusted with a role and a budget of fundamental importance to economic development. The legal basis (DL.no 66/80) for both a research university and the commercialisation of science was implemented only in the 1980's in Portugal. There were also difficulties in implementing this change, arising at the grass roots-level mainly for cultural and financial reasons (Ruivo, 1995).

If we accept the perspective of Etzkowitz and Leydesdorff (1997), we may say that in a certain way, Portugal is trying to do in one fell swoop what the advanced countries have done in two revolutions spaced over two centuries. Portugal is experiencing the first and second academic revolutions at the same time.

\section{The Portuguese "Research University"}

The Portuguese context has reached a sui generis version of the "research university." During the 1980's, teachers confronted with the legal obligation to do research took the initiative to found university research centres. These centres, however, were scientifically, administratively and financially autonomous, ${ }^{3}$ even though they worked on university premises and competed on the market using consulting enterprises so as to attract research projects, which would allow them to be self-financed. This allowed for greater working flexibility as the centres are free from the bureaucracy of the university organisation to which they are linked by means of teaching and management activities. In Portugal, most of the functions traditionally entrusted to university research, such as rendering services to the community and even ongoing training of senior personnel, is performed by these institutions. They are hybrids in that they have very strong ties with the universities and generally speaking were set up on the initiative of academics; they have a wide range of cooperation protocols, but remain independent of the universities. There is no detailed information on this phenomenon, but there is relative consensus that we are seeing a split of university activities, in as much as teaching and pedagogical activities tend to be centred on university departments and faculties, whereas $R \& D$ activities are located in the 
centres and institutes. Although the latter are linked to universities, they maintain for the most part administrative, scientific and financial autonomy. It is a hybrid model in which universities endogenise the new functions of research and render services to the outside. Universities are abandoning their "elite institution ivory tower" without great concern. What is happening, however, is that a sui generis organisational model has been found, with institutions independent from the universities performing most of the new functions attributed to them.

This is a Portuguese version of the Humboldt model and it is in this context that it seems appropriate to take up the questions raised at the start: what is the relationship between teaching and research? What kind of knowledge is the university to transmit? What is the relationship between the disciplines within the university? Does autonomy from the state imply a dependence on the market and what are the consequences of this process?

\section{Paradoxes and Ambiguities: Contributions to the Debate on the Future of the University}

\section{Ambiguity 1: \\ The Teaching-research Relationship}

Theoretically the teaching-research relationship has the virtue of progressing science, together with on-going training and keeping teachers up-to-date. It also has the function of diffusion, thus making the university the ideal place for the production, teaching and learning of scientific knowledge. But this virtuous circle presupposes a conception of dis- interested knowledge - that is independent of economic and political interests from Humboldt's perspective. This is contradictory to professional "made for the market" training, which seems to dominate the present spirit of the universities for a number of reasons. One of the most relevant is that the Portuguese economy's need for skills is not the same as in England or Germany, for example. This, in turn, contradicts the idea of the "European labour market," implicit in the principle of the free circulation of people within Europe. On the other hand, basic training no longer has a place in market-driven advanced research.

This contradiction leads, for example, to a large number of teachers in Portugal teaching subjects whose contents are unconnected to their research activities (Sousa Santos, 1994). Besides leading to an excessive workload, this also reflects on the quality of teaching and research (see Häyrinen-Alestalo et al., 2000). The circle becomes a vicious one in that it is the basis of the controversies critical of the universities and which arise from this ambiguity which should be clarified; if not there is the danger of using the same words for distinct things when we refer, for example, to the quality of teaching or the expectation which is generated in teachers, students, families, enterprises and society as a whole. This is a basic question, which cannot be left to the "invisible hand" of the market in higher education establishments.

\section{Ambiguity 2: \\ On the Multidisciplinary Problem}

There would seem to be a consensus, at least at the level of discourse that the 
multidisciplinary approach is the way forward for the development of so-called post-academic science. Some European science and technology programmes have already tried to develop such an approach. If we admit that the university is an important place for the production of scientific knowledge, ultimately this assumption implies a revolution in the university's internal organisation, given that the faculties and departments emerged precisely as a result of a disciplinary and specialised organisation of knowledge. The coherence of this model also implies that the organisation of courses, the division of increasingly specialised degree courses and the organisation of the teaching careers themselves are done on the basis of the disciplinary specialisation.

The multidisciplinary question is generally associated with the idea of forming flexible and temporary teams made up of many specialisations (Gibbons et al., 1994), however, this position ignores what the sociology of labour and of organisations has repeatedly shown regarding professional cultures and identities, (Sainsaulieu, 1977; Dubar, 1991;Oliveira, 1998) powering relationships, affirming strategies within organisations (Crozier \& Fiedberg, 1977; Sainsaulieu, 1987) and between disciplines (Serres, 1996; Caraça, 1999). This is why such experiences are usually unsuccessful.

\section{Ambiguity 3:}

\section{Autonomy From the State versus}

Dependence on the Market

This question is closely related to the previous ones as with the clarification of the university's mission. First, "science as the search for the truth," which is also what fundamental research is called, should not be confused with applied research, as often occurs. Fundamental research can and should, however, have an applied component. What is essential in this controversy is the definition of the objectives of research itself; that is, a model of science "as the search for the truth" - and it is in this sense that it is disinterested - or a science "as the search for the answer to economic and political interests." This is the split that in the past marked the difference between:

1. Academic research done in universities;

2. Industrial research, done in enterprises;

3. Research supporting political decision-making, done in research institutions, which work within the political sphere (study offices and institutes linked to ministries).

These differences tend to be tempered in "post-academic" science. Traditional science, in spite of its changing fortunes, has had the role of promoting and legitimising a critical culture, while not rejecting its experimental basis. This is of great importance in that the university's scope spreads much further and becomes a question of civilisation, however, it also calls on the academics, as the intellectual elite and important protagonists in this process, to make their position on the matter clear.

\section{Conclusion}

If the survival of science depends increasingly on its clients, be they public institutions or private enterprises, it also runs the serious risk of becoming a po- 
litically correct science. This question should be included in the analysis of the "risk society" (Beck, 1992), as the consequences of this kind of scenario could be tragic if we believe, as Caraça (1999) argues, that science is always an indispensable means for the construction of a vision of the world. In the context of the massification of higher education, along with the problem of unemployment in Europe, the temptation to compare universities with "professional" schools, which produce "ready to use" skills for the market, is understandable. But, if this is the new basis for universities, then the whole system should be reorganised accordingly.

\section{Notes}

1 Japan seems to have understood and satisfactorily resolved this problem through a "human resource recruitment and management policy" by enterprises, appropriate to a certain relationship between university and industry.(Jolivet, 1985)

2 Typology inspiredy by Rodrigues, Maria João, (1988), O Sistema de Emprego em Portugal, crise e mutações. Lisbon: D. Quixote.

3 This allows for greater working flexibility as they are free from the bureaucracy of the university organisation to which they are linked by means of teaching or management activies.

\section{References}

Beck, U.

1992 Risk Society, Towards a New Modernity. London: Sage Publications.

Boltanski, L. \& Chiapello, É.

1999 Le Nouvel Esprit du Capitalisme (The new spirit of capitalism). Paris: Gallimard.

Boyer, R.

1981 "Les transformations du rapport salarial dans la crise: une interpretation de ses aspects sociaux et économiques" (The crisis of changing salaries). Critiques de L'Économie Politique 15 \& 16: 185-228.

Bowker, G.

1996 "O desenvolvimento da investigação industrial," in Serres, M. (ed.), Elementos para uma História das Ciêcias III, de Pasteur ao compudator. Lisbon: Terra Mar.

Bush, V.

1945 Science, the Endless Frontier: a Report to the President. Washington.

Callon, M.

1994 "Four models for the dynamics of science" (mimeo).

Caraça, J.

1999 Science et Communication (Science and Communication). Paris: Puf.

Crozier, M. \& Fiedberg, E.

1977 L'acteur et le système (Actors and Systems). Paris: du Seuil.

Cruzeiro, E.

1990 Action symbolique et formation scolaire, l'université de Coimbra et sa faculté de droit dans la seconde moitié du XIX siécle (Symbolic Action and Education). Thèse pour le doctorat de Sociologie. Paris: EHESS.

Dias A.

1969 "As universidades portuguesas e a investigação científica e técnica" (Portuguese universities and research). Análise Social 5, 20-21: 127-144.

Dubar, C.

1991 La Socialisation, construction des identities sociales et professionnelles (Construction of social and professional identities). Paris: Armand Colin. 
Etzkowitz, H. \& Peters, L.

1991 "Profit From Knowledge: Organizational Innovations and Normative Change in American Universities." Minerva 29: 133-166.

Etzkowitz, H. \& Leydesdorff, L.

1997 Universities and the Global Knowledge Economy, a Triple Helix of UniversityIndustry-Government. London: Pinter.

Ferné, G. (ed.)

1993 Science, Pouvoir et Argent - la recherche entre marché et politique. (Science, power and money - a study between the markets and politics). Paris: Autrement.

Geiger, R.

1988 "Milking the Sacred Cow: Research and the Quest for Useful Knowledge in American University Since 1920.” Science, Technology \& Human Values 13, 3-4: 332-348.

Gibbons, M., Limoges, C., Nowotny, H., Schwartzman, S., Scott, P. \& Trow, M.

1994 The New Production of Knowledge: The Dynamics of Science and Research in Contemporary Societies. London: Sage.

Granovetter,M.

1973 “The Strength of Weak Ties.” American Journal of Sociology 78:1360-1380.

Habermas, J.

1993 Técnica e Ciência como "Ideologia" (Technology and science as 'ideology'). Edições 70, Lisbon.

Häyrinen-Alestalo, M., \& Peltola, U.

2000 "Universities Responding to the Pressure to Commercialise Their Knowledge Production." Paper presented at Worlds in Transition: Technoscience, Citizenship and Culture in the $21^{\text {st }}$ Century. Vienna.

Jolivet, M.

1985 L'université au service de l'économie japonaise (Universities serving the Kerr, C. Japanese economy). Paris: Economica.

1994 The Uses of the University, $4^{\text {th }}$ ed. Cambridge: Harvard University Press.

Lundvall, B.

1992 National Systems of Innovation. London: Pinter Publishers.
Lundvall, B. \& Borras, S.

1997 The Globalization of Learning Economy: Implications for Innovation Policy. Report based on preliminary conclusions from several projects under the TSER programme, DGXII.

Maurice, M., Sellier,F. \& Silvestre, J.

1982 Politique d'éducation et organisation industrielle en France et en Allemagne (Education policy and industrial organisation in France and Germany). Paris: Puf.

Nelson, R.

1993 National Innovation Systems, a Comparative Analysis. Oxford: University Press.

OCDE

1995 La formation a la recherche, aujoud'hui et demain (Research training today and tomorrow). Paris: OCDE.

1993 Politiques Nationales de la Science et de la Technologie, Portugal (National science and technology policy, Portugal). Paris: OECD.

Oliveira, L.

1998 "Monograph of National Higher Education and Research Systems," Relatório no âmbito do projecto Inovação e Sistemas de Ensino Superior, Programa TSER, DGXII.

2000 "Para uma abordagem sociológica do conceito de inovação" (A sociological approach to developing innovation). Relatório para a Fundação de Ciência e Tecnologia, Lisbon.

Peyrefitte, A.

1995 A Sociedade da Confiança. Lisbon: Instituto Piaget.

Renaut, A.

1995 Les Révolutions de l'Université, Essai sur la Modernisation de la Culture (University revolutions, an essay on cultural modernisation). Paris: Puf.

Rosenberg, N.

1985 Inside the Black Box: Technology and Economics. Cambridge: Cambridge University Press.

Ruivo, B.

1995 Science Policies in Portugal in International Perspective: 1967-1987. Lisbon: Casa da Moeda. 
Sainsaulieu, R.

1977 L'Identité au Travail, les effets culturels de l'organisation (Work identity, the effects of organisational culture). Paris: Presses de la Fondation National des Sciences Politiques.

Schumpeter, J.

1935 "Análise da Mudança Económica" (Analysis of economic change) first published in Review of Economic Statistics, and reedited in 1996, in Ensaios, empresários, inovação, ciclos de negócio e evolução do capitalismo. Oeiras: Celta Editora.

Serres, M. (ed.)

1996 Elementos para uma História das Ciências III, de Pasteur ao computador (The history of science III, from Pasteur to the computer). Lisbon: Terra Mar.

Sousa Santos, B.

1994 Pela Mão de Alice, o social e o político na pós-modernidade (The social and political in post-modernism). Porto: Afrontamento.

Vieira, M.

1995 “Transformações recentes do ensino superior" (Recent changes in higher education). Análise Social 30, 131-132.

Ziman, J.

1999 "Ethos and Ethics in Post-academic Science: Modes, Roles and Norms in a Pluralistic Culture," Paper presented at the IV European Sociological Conference "Will Europe work?" Amsterdam.

\section{Luísa Oliveira}

Instituto Superior de Ciências do

Trabalho e da Empresa (ISCTE)

University of Lisbon

Lisbon, Portugal 